This document is downloaded from DR-NTU (https://dr.ntu.edu.sg) Nanyang Technological University, Singapore.

\title{
Legal and regulatory aspects of transnational satellite broadcasting
}

Bhatia, Brajesh

1993

Bhatia, B. (1993). Legal and regulatory aspects of transnational satellite broadcasting.

https://hdl.handle.net/10356/93355 
Legal and Regulatory Aspects of Transnational Satellite Broadcasting

by

Brajesh Bhatia 
AMIC/BES (I) SEMINAR ON LEGAL AND REGULATORY

ASPECTS OF SATELLITE BROADCASTING

New Delhi, India

21 - 23 October 1993

LEGAL AND REULATORY ASPECTS OF TRANSNATIONAL SATELLITE BROADCASTING

by

BRAJESH BHATIA

Communication Consultant

\begin{abstract}
The last ten years or so have seen the widespread growth and influence of satellite communications in the Asia-Pacific region. Ultra-high frequency antennae and satellite dishes, capable of receiving both domestic and international broadcast programmes, have appeared and continue to mushroom in many places. The technological developments in this field have been so fast that most countries, especially the poor ones, have been caught unaware and possibly do not know what to do and how to cope with this "invasion". This "invasion" does not pose any threat to the national boundaries, but invades the airwaves and flouts censorship codes and imposes alien cultural mores and values, which may be considered as detrimental to national pride and conduct.
\end{abstract}

\title{
INTRODUCTION
}

The last ten years or so have seen the widespread growth and influence of satellite communications in the AsiaPacific region. This is evident in the expansion of telecommunication systems and facilities in many countries of the region. The region is also experiencing a wave of satellite broadcasting -- direct-to-home television services -- and to a certain extent it is revolutionizing the way people entertain themselves in the region.

Ultra-high frequency antennae and satellite dishes have appeared, and continue to mushroom in numerous places in Asia and the pacific. They receive both domestic and 
international broadcast programmes, either directly or through relay stations in these countries.

Networks have hooked up with BBC, CNN, SKY TV, STAR TV, etc. to be able to provide their audiences with more variety in viewing fare.

Non-traditional broadcasting institutions like hotels have entered into tie-ups with cable TV companies for the provision of entertainment programmes through their in-house video systems; business establishments have also linked up with these cable companies to access international business news and information.

Enterprising private individuals have also set up their own cable networks by setting up dishes in their backyards and roof tops to receive international programmes and linking the neighbourhood to a mini cable subscription operation. Some of these are within a existing legal framework of a country, while some are not. Transnational broadcasting has become a norm of the day.

The technological developments in this field have been so fast that most countries, especially the poor ones, have been caught unaware and possibly do not know what to do and how to cope with this "invasion". Even the poorest of the poor nations, at the cost of their development and in their bid to alleviate poverty, spend a substantial amount of money annually on their army, navy and air force to safeguard their territorial (land, sea and air space) integrity.

But this new kind of "invasion" does not pose any threat to their land, sea or air space frontiers, it invades their atrwaves (and there is no way that the clock can be turned back on the technology), flouts censorship codes and imposes alien cultural mores and values, which may be considered as detrimental to national pride and conduct.

The questions and issues to be discussed are:

* How have these developments affected the television programming policy of governments as well as broadcasting networks in the region?

* What are the variances in policy, relative to private vis-a-vis government networks? 
* What are the criteria applied by governments in allowing the entry of foreign cable television companies into their countries?

* How have the entry of foreign satellite- or cabletransmitted programmes affected the television programming and viewing patterns in the region?

* What is the impact of transnational programmes on local society and culture?

* What forms of control do or can national governments exercise to minimize some of the potentially negative effects of direct satellite broadcasting and/or foreign cable broadcasting?

* To what extent the transnational broadcasters follow the existing government regulations, institutional guidelines, and advertising codes of ethics?

* Do the existing laws relating to transmission and censorship and the advertising codes of ethics apply to the transnational broadcasting and can they adequately deal with the concerns being expressed in many quarters?

\section{DEVELOPMENTS AFFECTING PROGRAMMING POLICIES}

Until recently, broadcast programmers and policy makers in Asia were not concerned too much with what was happening to the broadcasting scene in the First World -- either in the form of technological developments or in the form of deregulation.

Satellite delivery system is not new or recent to the Asian broadcasting scene. For some years, Asian broadcasters have been using domestic and international satellites for the delivery of domestic programmes to far and away places within their respective countries, as well as for the coverage and delivery of international sporting events and news.

Even as recent as about two years ago when STAR TV began its transnational free-to-air television delivery system from Hong Kong using the communications satellite Asiasat 
1* launched in April 1990, very few terrestrial broadcasters in the region took any serious note of this development.

They were not particularly distressed because of the impression that people belonging to certain culture or cultures and capable of understanding their own mother tongues only, so to say, would always like to watch television programmes in their own language and of relevance to their culture.

However, they were proved wrong by the massive popularity of STAR TV's initial four channels and later addition of the fifth channel, ZEE TV. They were also under the impression that antiquated laws and regulations (some of them were framed 100 years ago) would take care of the unauthorized proliferation of cable television. According to unofficial estimates, about 20 per cent of television households in India are currently hooked to STAR TV.

If the national broadcasters really want to keep their audience in their fold, they have to have a serious look and introspection of their programming policies, as well as their delivery channels and make some drastic changes to make their television fare interesting. They have to make certain far reaching decisions before it is too late.

India, for example, has launched five new channels delivered through satellite. But is the delivery enough, without looking at who is receiving what and how?

\section{VARIANCE IN POLICY : PRIVATE VS GOVERNMENT NETWORKS}

For a long time, the government television networks have enjoyed a monopoly even under the most democratic regimes, and probably contravening the constitutional or fundamental rights of the people. This situation has made the government broadcasters apathetic to the changing needs and expectations of their audiences.

There is nothing like a homogenous audience among the television viewers. One has to cater to a wide variety of

* The signals from this satellite can be received by 38 countries in the Asia-Pacific region. 
audience and meet their expectations. To a certain extent the policy to allow private television stations to operate in direct competition to the government networks is meeting the entertainment needs of the people.

Most of the time private stations have to conform to the government rules and regulations and have to tow the government line as the licence to operate has to be renewed from time to time.

\section{CRITERIA APPLIED BY GOVERNMENTS IN ALLOWING FOREIGN CABLE} COMPANIES

Usually, the governments in the region have certain regulations governing the operations of foreign companies in all sectors and such rules would, in normal course, also be applicable to the media companies.

In addition, keeping in view the sensitive nature of media operations, the governments in the region are more careful in selecting the foreign cable companies to operate in their countries.

More often, the governments prefer to have majority share holdings in such ventures to keep a tighter control on operations of such companies/joint ventures.

Control is the keyword -- keeping control on the content and keeping control of the revenue. Can privatization of government television networks help in redeeming the situation?

\section{TELEVISION PROGRAMMING AND VIEWING PATTERNS}

The entry of transnational satellite broadcasting, especially free-to-air services, has definitely affected the television operations of national broadcasting organizations and has forced them to realize that their monopoly on holding their viewers is in danger.

These services, originating from outside the national boundaries of their viewers, have for the first time offered a choice, hitherto unknown or unheard of, in television viewing. 
In many cases, the viewers do not understand the language of these telecasts nor can comprehend fully the programmes offered, but in contrast it is a feast to their eyes.

How long this courtship is going to last? National broadcasters by and large feei that transnational broadcasters cannot keep their viewers glued for a long time, because viewers want to watch programmes in their own languages and and in an ambience to which they can relate to.

In reply, transnational broadcasters have now started or planning to provide services in many languages which their viewers can understand.

National broadcasters have also started taking steps to provide more choices to their viewers in terms of opening new channels and better programming.

But one thing is certain, it is going to be a boom time for the aspiring video producers and the quality of television programmes produced in the region is bound to improve because of the keen competition for the attention of viewers which is going to take place.

IMPACT OF TRANSNATIONAL BROADCASTING ON NATIONAL CULTURE AND SOCIETY

Some twenty years ago, television was called a "one-way street" and a threat posed by the imported (mainly from Hollywood) television programmes to the Asian cultures and societies was highlighted by many researchers (e.g. Kaarle Nordenstreng, Tapio Varis, Bhatia, etc.).

It was assumed that the United states, Britain and France were trying to extend a new kind of "colonialism" by imposing Western values on the Third World countries through the massive export of television programmes produced in their countries.

Excessive violence, shown in these imported serials, was another major concern to Asian broadcasters.

Several Asian countries, including India, had, therefore, resorted to some kind of ban on the import of television programmes to stop this "invasion". 
It was quite possible to do so some fifteen or twenty years ago, since broadcasting was limited to terrestrial transmission only. But now it has almost become impossible to ban or restrict transnational broadcasting through satellites.

FORMS OF CONTROL

Such "threats" -- in the form of imposition of alien cultures and excessive violence -- could be averted at that time by restrictions imposed by the national governments on the importation of television programmes and those restrictions could work in favour of terrestrial broadcasters.

But now the technology has leaped to that extent that restrictions are virtually impossible either on the transmission or on the reception of television programmes. Uplinking from any part of the world is possible now and similarly the miniaturization of reception equipment makes it impossible to police and detect such unauthorized receptions even if the governments have a suitable legislation.

CENSORSHIP RULES AND CODE OF ETHICS PERTAINING TO PROGRAMMES AND ADVERTISEMENTS

Keeping in view the nature of television viewing, even the most liberal societies have some kind of broad understanding as to what can be shown or what cannot be shown on television.

Almost all Asian countries have censorship rules for television programmes and also enforce a code of ethics to be followed by television networks and advertising agencies.

For example, most countries do not allow sex-explicit scenes (such as kissing) or excessive violence in television programmes.

Similarly, advertising of liquor and tobacco products is not permitted in most countries. 
Imposition of national censorship guidelines and code of ethics pertaining to advertisements is only possible on television networks originating programmes within the national boundaries.

How does one enforce these rules and guidelines on the transnational broadcasters transmitting programmes from foreign soil?

Do these transnational broadcasters have any guidelines in these matters or are they simply interested in broadening their base of viewers and thereby amassing advertising revenue from the "bad guys"?

Some countries are now thinking of new legislation to curb the spread of cable networks. Will it be possible to implement those legislation or will it remain on paper only?

WHAT NEEDS TO BE DONE

The famous saying, "if you cannot win them or stop them, the best course is to join them", perfectly fits in this case.

Obviously, the technological leap cannot be stopped or reversed. The stage has been reached that nothing can stop this "invasion" of our airwaves.

There are only two possibilities. One, the national broadcasters should come up with universal guidelines for programmes as well as for advertisements and then transnational broadcasters should be persuaded to adhere to them. But there is no guarantee that this can be implemented fully.

Second choice is that national broadcasters in the region could join hands together and begin operating a satellite delivery system of their own in direct competition with transnational broadcasters from outside the region.

It is not an impossible or improbable choice, but it needs greater understanding, a political will and above all a commitment to provide a healthy mix of television programming to our ultimate masters -- the viewers. 
Table 1

SELECTED DEMOGRAPHIC CHARACTERISTICS OF THE REGION

\begin{tabular}{|c|c|c|c|c|c|c|}
\hline & $\begin{array}{l}\text { Popula- } \\
\text { tion } \\
\text { million }\end{array}$ & $\begin{array}{l}\text { Popula- } \\
\text { tion } \\
\text { Growth } \\
\text { \& }\end{array}$ & $\begin{array}{l}\text { GNP } \\
\text { Per } \\
\text { capita } \\
\text { USS }\end{array}$ & $\begin{array}{l}\text { GDP } \\
\text { growth } \\
\text { क }\end{array}$ & $\begin{array}{c}\text { Literacy } \\
\text { rate } \\
\text { \& }\end{array}$ & $\begin{array}{r}\text { People } \\
\text { per } \\
\text { phone }\end{array}$ \\
\hline Bangladesh & 123.1 & 2.7 & 220 & 4.0 & 35.3 & 455.0 \\
\hline Bhutan & 0.6 & 2.3 & 415 & 5.0 & 38.0 & 285.0 \\
\hline India & 883.1 & 2.1 & 310 & 4.2 & 52.1 & 126.6 \\
\hline Maldives & 0.2 & 3.4 & 470 & 6.3 & 98.2 & 19.5 \\
\hline Nepal & 20.4 & 2.3 & 180 & 3.1 & 26.0 & 196.0 \\
\hline Pakistan & 122.5 & 2.9 & 425 & 3.0 & 35.0 & 89.3 \\
\hline Sri Lanka & 17.7 & 1.0 & 550 & 4.3 & 88.5 & 100.0 \\
\hline
\end{tabular}

Source: ASIAWEEK, 21 July 1993. 
Table 2

SOURCES OF HOME ENTERTAINMENT IN THE WORLD BY REGION (NUMBER OF TELEVISION AND RADIO RECEIVERS IN USE) (IN MILLIONS)

\begin{tabular}{|c|c|c|c|c|c|c|}
\hline \multirow[t]{2}{*}{ REGION } & \multicolumn{2}{|c|}{ POPULATION } & \multicolumn{2}{|c|}{ TELEVISION } & \multicolumn{2}{|c|}{ RADIO } \\
\hline & Number & \% & Number & \% & Number & \% \\
\hline AFRICA & 476.66 & 9.2 & 18 & 1.7 & 73 & 3.5 \\
\hline AMERICA, NORTH & 273.93 & 5.3 & 202 & 19.2 & 608 & 29.6 \\
\hline AMERICA, SOUTH & 437.21 & 8.5 & 88 & 8.4 & 171 & 8.3 \\
\hline ARAB WORLD & 215.10 & 4.1 & 38 & 3.6 & 75 & 3.6 \\
\hline ASIA & $2,947.28$ & 57.2 & 329 & 31.3 & 524 & 25.5 \\
\hline OCEANIA & 26.03 & 0.5 & 10 & 1.0 & 30 & 1.5 \\
\hline EUROPE-USSR & 786.20 & 15.2 & 366 & 34.8 & 575 & 28.0 \\
\hline TOTAL & $5,162.41$ & 100.0 & 1,051 & 100.0 & 2,056 & 100.0 \\
\hline
\end{tabular}


Table 3

NUMBER OF RADIO SETS PER THOUSAND POPULATION

\begin{tabular}{|c|c|c|c|c|}
\hline 1970 & 1980 & & 1989 & 2000 * \\
\hline Bangladesh & & & 41 & 85 \\
\hline Bhutan & 3 & 6 & 15 & 45 \\
\hline India & & 38 & 78 & 165 \\
\hline Maldives & 11 & 45 & 115 & 290 \\
\hline Nepal & 5 & 20 & 33 & 50 \\
\hline Pakistan & 64 & 86 & 115 & \\
\hline Sri Lanka & 52 & 98 & 194 & 400 \\
\hline
\end{tabular}


Table 4

NUMBER OF TELEVISION SETS PER THOUSAND POPULATION

\begin{tabular}{|c|c|c|c|c|}
\hline & 1970 & 1980 & 1989 & $2000 *$ \\
\hline $\begin{array}{l}\text { Bangladesh } \\
\text { Bhutan }\end{array}$ & 0.1 & 0.9 & 4.4 & 25.0 \\
\hline India & 0.4 & 4.4 & 27.0 & 75.0 \\
\hline Maldives & & 7.1 & 24.0 & 75.0 \\
\hline Nepal & & 1.6 & 10.0 & \\
\hline Pakistan & 1.5 & 11.0 & 15.8 & 40.0 \\
\hline Sri Lanka & & 2.4 & 32.3 & 95.0 \\
\hline
\end{tabular}

* Estimated 


\title{
BRIEF BIOGRAPHY OF MR BRAJESH BHATIA
}

Mr Brajesh Bhatia is a communication consultant by profession and runs two companies -- Fourth Dimension (M) Sdn Bhd which provides computer graphics services and based in Kuala Lumpur and Visual Media Resources (Asia) Pte Ltd in Singapore -- serving broadcasting organizations in the region. Before venturing on his own in late 1989, he was deputy director at the Asia-Pacific Institute for Broadcasting Development. Well known in the region as a broadcasting trainer, for the past twenty years he has worked at the United Nations Eoonomic and Social Commission for Asia and the Pacific, Bangkok, Thailand; Asian Mass Communication Research and Information, Singapore; and the Asia-Pacific Institute for Broadcasting Development, Kuala Lumpur.

Contact Address:

\author{
Mr Brajesh Bhatia \\ Managing Director \\ Fourth Dimension (M) Sdn Bhd \\ 50-B Jalan 1/19 \\ 46000 Petaling Jaya, Selangor \\ Malaysia \\ Phone: \\ (6010) 214974 \\ Fax: \\ (603) 793-0352
}

